\title{
DEVELOPMENT A MECHANICAL STIRRING UNIT FOR DRYING RICE GRAINS
}

\author{
Mokhtar C. Ahmed*
}

\section{ABSTRACT}

The present study was carried out to develop and evaluate the performance of a mechanical stirring unit for rice crop after harvesting for drying to increase stirring efficiency and decrease both power and cost requirements. The aim of this study is to develop a mechanical stirring-unit for drying rough rice-grains after harvesting. The performance of the developed stirring unit was studied as a function of change in screw paddles speed of (120, 180 and 300 rpm ), paddle inclination angle of( zero, 15 and 30deg) with two paddle shapes (trapezoid and rectangle) and a unit wheel width of (4 and $10 \mathrm{~cm}$ ). The developed unit performance was evaluated in terms of unit capacity, stirring efficiency and required power. The results showed that the screw trapezoid paddle with inclination angle of $30^{\circ}$ decreased specific power by $15.79 \%$ and $20.83 \%$ by increasing paddle speed from 120 to 180 rpm and from 180 to $300 \mathrm{rpm}$, respectively. While, under the same conditions, stirring efficiency increased by $4.39 \%$, and volumetric capacity decreased by $8.8 \%$ and $17.6 \%$ under conditions of increasing inclination angle from zero to $15^{\circ}$ and to $30^{\circ}$, respectively at the same screw pitch of $20 \mathrm{~cm}$ with layer height of $7.0 \mathrm{~cm}$. Total costs with the use of the developed stirring unit decreased by $48.2 \%$ comparing to the traditional method (by feet) according to hiring laborers with recent prices.

\section{INTRODUCTION}

I n Egypt, rice has been sun dried for years. Sun drying (exposing the product being dried to direct sunrays) is still the most common method used to preserve the agricultural products in most small Egyptian farms and producers. Rice is either spread in the field to dry; gathered into panicles or sheaves and placed on pavement or hung from frames; gathered and dried on nets, mats or canvas; or gathered and placed in a drying barn or grain mill floor.

*Agricultural Engineering Research Institute, Agric. Res. Center, Dokki-Giza 
Each method works but has particular problems that must be watched. The traditional method is used by many farmers as it is easy, low cost, widely available, and gives comparable results to more costly mechanized drying methods and also more friendly to the environment. The rice quantity dried by dryers occupied one third of total production because most of the farmers sell fresh rice after harvest. At harvest time rice grain contains a lot of moisture, typically between 20-25\%. At such high grain moisture contents there is increased natural respiration in the grain that causes deterioration of the rice. Wet seed, is more vulnerable to pest and disease attack and to deterioration in physical quality. Wet seed also leads to natural respiration during storage creating "hot spots" within the seed lot. These hot spots promote the growth of insects and the development of fungi and other pathogens. Seed life is doubled by each $1 \%$ reduction in moisture content below $14 \%$. In general, the longer the intended period for storage, the lower the moisture content should be, i.e. the more you have to dry the seed. Rice constitutes the staple food for a large proportion of the world's population (Evanson et al., 1996), and its consumers represent one of the most demanding cereal markets with regards to product quality. Kernel quality is thus of utmost importance to the rice processing industry. Soetoyo and Soemardi (1979) demonstrated that paddy can be dried from $24-26 \%$ moisture to $14 \%$ moisture at depths of $50-100 \mathrm{~mm}$ at a rate of $3.3 \mathrm{~kg} / \mathrm{m}^{2} . \mathrm{h}$ for stirred paddy and $1.9 \mathrm{~kg} / \mathrm{m}^{2} . \mathrm{h}$ for unstirred paddy. The grain can reach temperatures as high as $60^{\circ} \mathrm{C}$ under clear skies and the rate of drying can be extremely high. Under these circumstances kernel cracking and loss of head rice can be appreciable, particularly if paddy is dried to below $14 \%$ moisture. Covering the paddy around midday may be beneficial under particularly hot and sunny conditions. Teter (1987) noted that seed paddy can be sun dried at depths of up to $30 \mathrm{~mm}$ but that the final stages of drying to $12 \%$ moisture should be conducted in the shade to avoid overheating and kernel cracking. Flat-bed dryers can be used with bed depths of up to $0.3 \mathrm{~m}$, air temperatures not exceeding $40^{\circ} \mathrm{C}$, and airflows of $1.3-1.7 \mathrm{~m} 3 / \mathrm{s}$ per ton of grain.

Jeon et $\boldsymbol{a l} ., 1989$ stated that all equations were used in many studies concerning thin-layer drying modelling. Rice kernels crack if rewetted 
when below a critical moisture content of $13 \%$ to $16 \%$. Since the distribution of individual kernel moisture in the panicle is non uniform, cracking or fissuring of some kernels on the standing crop will begin when the average grain moisture drops below 25\% for medium grain varieties. Proctor, 1994 stated that the traditional practice of grain drying is to spread crop on the ground, thus exposing it to the effects of sun, wind and rain. The logic of this is inescapable; the sun supplies an appreciable and inexhaustible source of heat to evaporate moisture from the grain, and the velocity of the wind to remove the evaporated moisture is, in many locations, at least the equivalent of the airflow produced in a mechanical dryer. In tropical countries, for at least several months of the year, the mean level of insolation upon the ground is more than 0.5 $\mathrm{kW} / \mathrm{m}^{2}$ (measured as a mean over the hours of daylight). The heat available therefore, assuming a 12 hour day, is $21.6 \mathrm{MJ} / \mathrm{m}^{2}$, a quantity theoretically sufficient to evaporate $9 \mathrm{~kg}$ of water.

Bonazzi et al. 1997 mentioned that to prevent rice damage following harvest of a high moisture content product, the paddy should be dried to such a level of moisture content that will enable safe storage by reducing respiration, and by a prevention of mycotoxins production. This corresponds to a moisture content of about 13-14\% (w.b.), which is considered as admissible for safe storage, safe milling and subsequent safe storage as milled rice, with low fungus and insect attack, leading to a minimum deterioration of chemical components, and a minimum of subsequent loss in nutritive values.

Two of the main indices used to determine rice quality are head-rice yield and head-rice color. Head-rice yield is accepted as the current measure of commercial physical quality and is defined as the mass percentage of rough rice kernels that remains as head-rice (kernels that are at least 3/4 of the original kernel length) after complete milling. Other frequently reported rice quality parameters include pasting properties, chemical properties, and sensory quality (Daniels et al., 1998; Meullenet et al., 1999; Pearce et al., 2001; Ranalli et al., 2003; Zhou et al., 2003). Post-harvest management of rice plays an essential role in maintaining rice quality. Rough rice is normally harvested at moisture content ranging from $14 \%$ to $26 \%$. High-MC rice kernels are subject to 
elevated respiration rates due to enzyme activity and mold growth (Dillahunty et al., 2000), which reduce the dry matter content of rice and may produce sufficient energy to be detrimental to product quality (Bradburn et al., 1993). It is generally considered that under typical storage environments, the $\mathrm{MC}$ of rough rice must be reduced to less than $13 \%$ for safe long-term storage.

The development of rice drying techniques was the subject of many studies during these last decades. These studies led to the development of industrial and semi-industrial dryers, unfortunately limited by their costs. In addition to these industrial or artificial methods, other drying methods, known as traditional or natural ones, use sun as energy source. The purpose of this study are to develop and evaluate the performance of a mechanical stirring-unit for drying rough rice-grains after harvesting in order to reduce rice moisture content to the safe level for storage.

\section{MATERIALS AND METHODS}

A study was conducted at El-Serw Agricultural Station to develop and evaluate a hand-propelled unit for stirring rough rice grains after harvesting for sun-drying. It is crucial in sun-drying to stir the seed regularly. This can be done using feet (Fig. 1), by dragging feet through the layer of seed and at the same time mixing and stirring but it is an exhausting task. Rakes (Fig. 2) are also a very effective tool to do this notwithstanding its difficulty. Drying on flat exposed surfaces is the most common way of drying grain after harvesting and threshing. For drying small amounts on the farm grain may be spread on any convenient area of land. Cleaner dried grain can be obtained by drying the grain on plastic sheets, preferably black.

Purpose-constructed drying floors are commonly used where there is a need to dry large quantities of grain during the season, e.g. at most rice mills. The floors are usually made of concrete or brick, these materials presenting a relatively smooth and hardwearing surface. Floors should be constructed to withstand the movement of vehicles and sloped or channeled to hasten the runoff of rainwater in rainy regions. The paddy is spread in a thin layer on the floors and raked at intervals, preferably 7-8 times daily, to facilitate even drying. At night the paddy is heaped into 
rows and covered with sheeting. In all cases rough rice is covered at night and when it rains to prevent cracking. (Fig. 3)

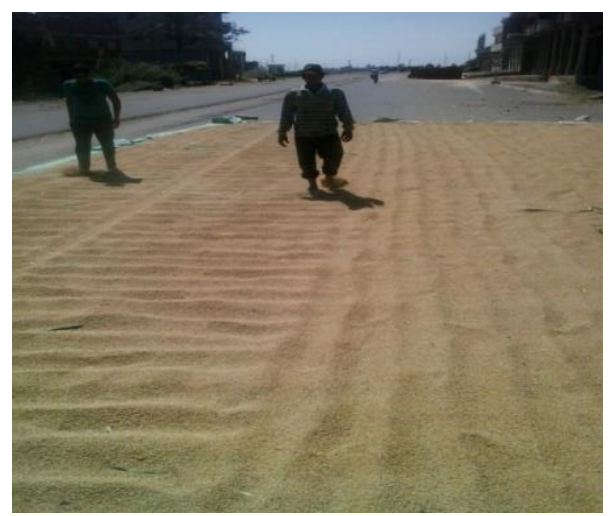

Fig. 1: Traditional stirring rice (by feet).



Fig. 2: Rakes used for rice stirring.

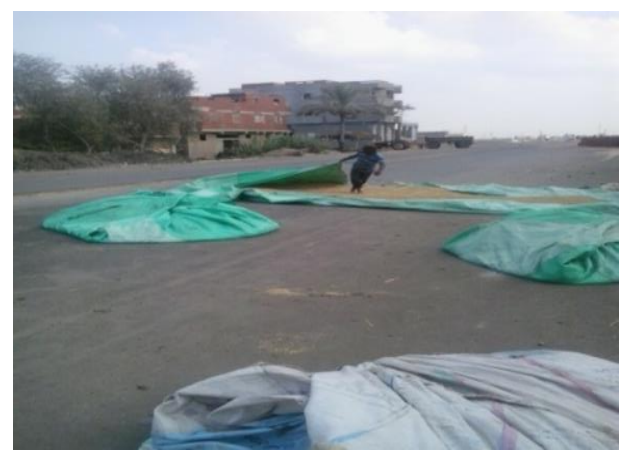

Fig. 3: Covering rice after sun-drying.

In addition, there are machines now available for mixing the grains. Therefore, a field trial has been conducted to evaluate a developed mechanical stirring unit for sun-drying rice crop directly after harvesting.

\section{The developed stirring unit}

The developed stirring unit consists of the following main parts (Fig 4):

- The frame: The frame is made of a cylindrical steel tube 1.0 inch fixed on three tubeless wheels and provided with a steering arm looks like the cart chassis. The maximum length, width and height are 175, 105 and 90 $\mathrm{cm}$, respectively.

- The wheels: Three tubeless ground wheels with $30 \mathrm{~cm}$ diameter, one in the front and two at rear, were used for carrying the main chassis. The two rear wheels are responsible for providing the motion to the stirring 
drum and the front wheel is used for adjusting the stirring depth according to rice layer thickness.



Fig. 4: A photo of the hand-propelled stirring unit

- The stirring drum: The impellers were tested individually for determining the most suitable one (Fig. 5). Three types of impeller (auger, paddle and flat blade disc turbine) were tested under the same conditions (Figs. 6 and 7).

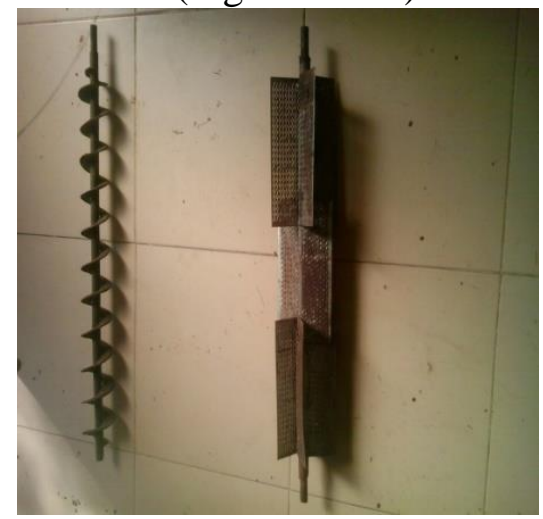

a) auger (b) flat blade turbine



(c) paddle

Fig. 5: Tested stirring drums

Paddle drum was used for complete stirring material. Paddles may be fixed (welded in place) or adjustable pitch (bolt mounted, to provide 
variable degrees of mixing). The screw is developed for maximum reliability. After testing adjustable paddles, the paddle screw was welded with a maximum inclination of $30^{\circ}$. Paddle screw material are ST 52.3 and stainless steel 304.

- Motion transmission system: Three different sprockets diameter on the rear axle with a sprocket of $5 \mathrm{~cm}$ diameter on paddle axle with a chain were used for transmitting the motion needed for driving the stirring screw from the rear tubeless wheels. The three different sprocket diameters gave 2, 3, and 5 revolution per second. The rear sprocket is fixed on the rear axis driven by the two ground wheels which consequently transmits the motion to the $5 \mathrm{~cm}$ sprocket fitted on the stirring screw paddle axis through a chain.

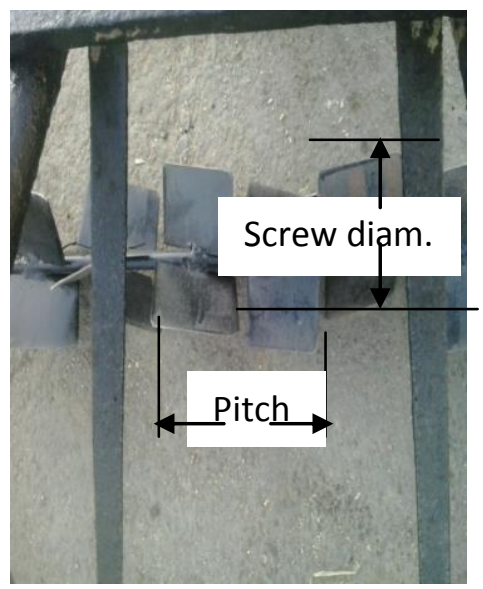

Fig. 6: Fixed paddles screw diameter and pitch.

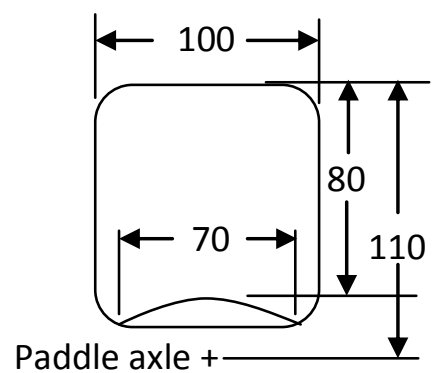

a) rectangle paddle



Fig. 7: Disc turbine with flat blade.

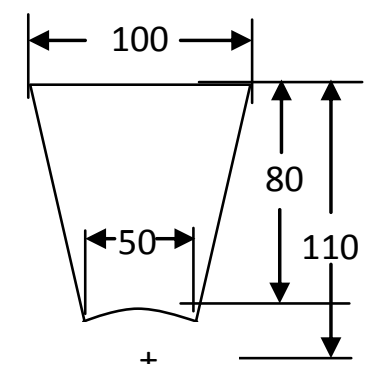

b) trapezoid paddle

Fig. 7: Peddle shapes 


\section{Rice grain samples:}

Samples of grain rice of Giza 178 variety were used for all tests. The samples were provided from the farm of El-Serw Agricultural Research Station in Damietta, with an initial moisture content of $20 \%$ d. b. This process was carried out at a mean temperature of about $34^{\circ} \mathrm{C}$ according to official weather forecast of Damietta region.

\section{Test factors}

- Tubeless wheels width: Wheel widths of 4 and $10 \mathrm{~cm}$ with $30 \mathrm{~cm}$ diameter were tested under different conditions.

- Inclination angle: Inclination angles of zero, 15 and $30^{\circ}$ were tested under different rotational speeds of 120, 180 and $300 \mathrm{rpm}$ for the screw paddles.

- Shapes of paddle: Paddles shape of rectangular and trapezoid paddles were tested under different conditions.

- Grains rice thickness of 7,10 and $15 \mathrm{~cm}$ was tested under different parameters.

- Screw paddle types of auger, flat blade disc turbine and paddle were tested.

- As the developed unit is manually driven, ground speed was considered constant depending on the operator motion.

In remote trails, wheel width, seed layer thickness, stirring drum shape (auger, plates and paddle), paddle pitch were tested individually and the characteristics, according to best performance of each parameter, was chosen and determined for proceeding all following treatments.

Experimental procedure: In a completely randomized factorial design, all treatments were carried out with four replicates for each treatment either for the main trails or for the remote trails and the obtained data were tabulated and statistically analyzed.

- Moisture content: Rice moisture content was measured per hour by a moisture meter device used specially for this purpose. This device is available at Agron. Research Lab., El-Serw Agricultural Research Station, Damietta.

\section{Measurements}

- The theoretical volumetric capacity: The theoretical volumetric capacity of the screw by Srivastava (1993) is defined as: 


$$
Q_{t h}=\frac{\pi}{4}\left[\left(d_{s f}\right)^{2}-\left(d_{s s}\right)^{2}\right] I_{p} N
$$

where

$\mathrm{Q}_{\mathrm{th}}$ : the theoretical volumetric capacity, $\mathrm{cm}^{3} / \mathrm{min}$

$\mathrm{d}_{\mathrm{sf}}$ : screw flight diameter, $\mathrm{cm} ; \mathrm{d}_{\mathrm{ss}}$ : screw shaft diameter, $\mathrm{cm}$

$\mathrm{I}_{\mathrm{p}}$ : pitch length, $\mathrm{cm} ; \quad \mathrm{N}$ : screw rotational speed, $\mathrm{rpm}$

\section{Stirring unit capacity}

Stirring unit capacity (SUC) can be calculated using the following equation:

$\mathrm{SUC}=\mathrm{Q}_{\mathrm{a}} \times \rho_{\mathrm{b}}(\mathrm{kg} / \mathrm{min})$

$\mathrm{Qa}=$ Volumetric capacity, $\mathrm{cm}^{3} / \mathrm{min}$.

$\rho_{\mathrm{b}}=$ Seed bulk density, $\mathrm{kg} / \mathrm{m}^{3}$

- Stirring efficiency: Stirring efficiency was calculated according to the time needed (hours/ton) for desirable sun-drying.

$$
\eta=\frac{Q_{a}}{\frac{\pi}{4}\left(d_{s f}^{2}-d_{s s}^{2}\right) I_{p} N}
$$

Where,

$$
\begin{aligned}
& \eta=\text { Efficiency, } \% \\
& Q a=\text { Volumetric capacity, } \mathrm{cm}^{3} / \mathrm{min} .
\end{aligned}
$$

- Specific power: Providing the unit is manually driven by the operator with $0.1 \mathrm{hp}$, power requirements was estimated in case of reaching seed optimum moisture content recommendable for storing and consequently the specific power was estimated as follows:

$$
P^{0}=\frac{P \times 60}{L \times Q_{a} \times \rho_{b} \times 1000}(\mathrm{~kW} . \mathrm{s} / \mathrm{kg} . \mathrm{m}) .
$$

Where,

$$
\begin{aligned}
& P^{0}=\text { Specific power, } \mathrm{kW} . \mathrm{s} / \mathrm{kg} . \mathrm{m} \quad P=\text { Total power, Watt. } \\
& L=\text { Screw length, } \mathrm{m} \quad \rho_{\mathrm{b}}=\text { Seed bulk density, } \mathrm{kg} / \mathrm{m}^{3}
\end{aligned}
$$

\section{Operational cost:}

The operational cost was determined using the following equation:

$$
\text { Operating } \cos t=\frac{\text { machine cost }, \text { L.E } / h}{\text { eff } . \text { field capacity, fed } / h}, \text { L.E/ fed. }
$$

Effective field capacity: It was determined by using the following formula: 


$$
P_{a c t}=\frac{60}{T_{u}+T_{i}}, \quad \text { fed } / h
$$

Where:

Pact: The actual capacity of the machine, fed/h

Tu : the utilized time per fed, min.

Ti the summation of time lost per fed, min.

Field efficiency $(\zeta)$ : It was calculated using the following formula:

$$
\zeta=\frac{\mathrm{P}_{\mathrm{act}}}{\mathrm{P}_{\mathrm{th}}} \times 100
$$

Where, $\mathrm{P}_{\text {th }}$ is the theoretical field capacity, fed/h.

\section{Statistical analysis:}

All experiments were done and data were analyzed using SPSS software. A completely randomized factorial design of two factors along with Dunken Test for means differences at 5\% level were applied.

\section{RESULTS AND DISCUSSION}

\section{Effect of wheel width and paddle shapes on specific power under}

\section{different paddle speeds.}

Fig. 8 showed the effect of wheel width (contact area) on specific power under different conditions of paddle shape and paddle speed. It was obvious that specific power increased by $47.54 \%$ by increasing wheel width from 4 to $10 \mathrm{~cm}$ with trapezoid paddle under the same speed of 120 rpm. The same trend was shown under 180 and $300 \mathrm{rpm}$ paddle speeds with the same conditions. While under the rectangle paddle shape, specific power increased by $56.96 \%$ under the same conditions of trapezoid shape. It could be concluded that using wheel width of $10 \mathrm{~cm}$ resulted in increment of about $9.42 \%$ specific power either with trapezoid or rectangle paddle shape under different paddle speeds. Generally, small wheel width of $4 \mathrm{~cm}$ showed less specific power values in all treatments $\left(\mathrm{y}=0.0004 \mathrm{x}+0.22\right.$, and $\left.\mathrm{R}^{2}=0.8929\right)$ for rectangle shape and $(\mathrm{y}=$ $0.0005 x+0.1686$, and $R^{2}=0.9098$ ) for trepozoid shape and consequently these results objected using smaller wheel width of $4 \mathrm{~cm}$ for carrying out all other treatments. These results may be attributed to the excessive power needed to overcome the grains resistance with $10 \mathrm{~cm}$ wheel width especially with high paddle speeds of 180 and $300 \mathrm{rpm}$. 



Fig. 8: Effect of wheel width and paddle shapes on specific power under different paddle speeds

\section{Effect of paddle speed and paddle shapes on specific power under}

\section{different inclination angles.}

Fig. 9 shows the effect of paddle speed and paddle shape on specific power under different inclination angles. It could be concluded that increasing paddle speed resulted in increasing specific power under different conditions of inclination angle and paddle shape. Specific power increased by 15.79 and $20.83 \%$ by increasing paddle speed from 120 to $180 \mathrm{rpm}$ and from 180 to $300 \mathrm{rpm}$, respectively under zero inclination angle with trapezoid paddle shape. These results may be due to the more power consumed to overcome the sudden impact between the paddles and grains under high paddle speeds which showed the obtained results. Similar trend was shown under rectangle paddle shape but specific power increased by $20 \%$ than trapezoid shape under the same conditions of paddle speed and inclination angle. These results may be because of the more contact area exposed to the grains with rectangle shape which needed more power than trapezoid shape which needs less power according to small contact area. While under inclination angles of $15^{\circ}$ and $30^{\circ}$, specific power decreased by 18.75 and $31.25 \%$, respectively. Generally, trapezoid paddle shape under paddle speed of $120 \mathrm{rpm}$ with inclination angle of $30^{\circ}$ showed the least value of specific power although 
inclination angle of $15^{0}$ showed the best results for stirring efficiency. Data analyzed showed a significant effect for paddle speed and inclination angle on specific power. $\mathrm{y}=0.0004 \mathrm{x}+0.1086$ and $\mathrm{R}^{2}=$ 0.9978 for zero inclination angle; $y=0.0004 x+0.0871$ and $R^{2}=0.9884$ for $15 \mathrm{deg}$. inclination angle and $\mathrm{y}=0.0004 \mathrm{x}+0.0586$ and $\mathrm{R}^{2}=0.9978$ for $30 \mathrm{deg}$. Inclination angle.
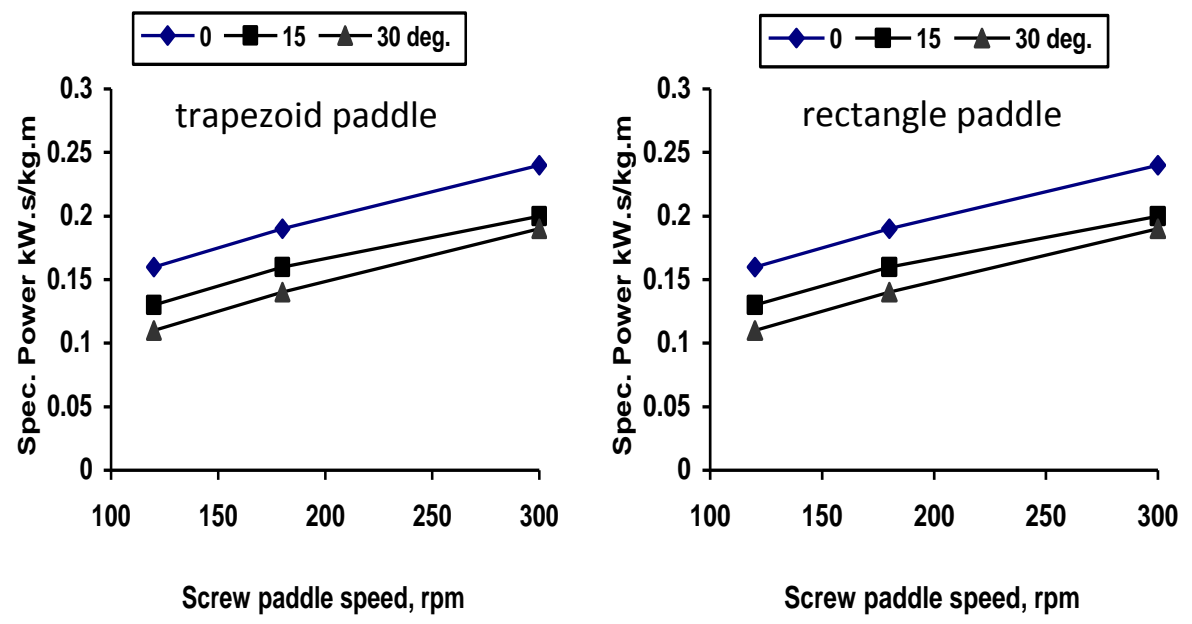

Fig. 9: Effect of screw paddle speed and paddle shape on specific power under different inclination angles

Effect of screw paddle speed and paddle shape on stirring unit capacity under different inclination angles

Fig. 10 illustrated the effect of screw paddle speed and paddle shape on stirring unit capacity under different inclination angles. Increasing inclination angle resulted in decreasing stirring unit capacity according to lessen friction force between paddles and seeds. The stirring unit capacity decreased by $8.8 \%$ and $17.6 \%$ while increasing inclination angle from zero to $15^{\circ}$ and to $30^{\circ}$, respectively. These mentioned results were under trapezoid paddle shape. While under triangle paddle shape, stirring unit capacity decreased by $4.1 \%$ and $13.18 \%$ while increasing inclination angle from zero to $15^{\circ}$ and to $30^{\circ}$, respectively. These results may be attributed to the faced position of the paddle (zero degree) with grains which caused more shifting for grains with less stirring. Whereas, under 
other inclination angles of 15 and 30 degree, the incline position allowed the grains to be stir badly while sliding on paddles with less shifting. It was clear that the changeable paddle speed had no effect on stirring unit capacity as the paddle screw only stir the seeds without shifting. Also, the operator motion was considered stable and the increment in paddle screw revolution is only a result of changing sprockets diameter not according to operator forward speed.
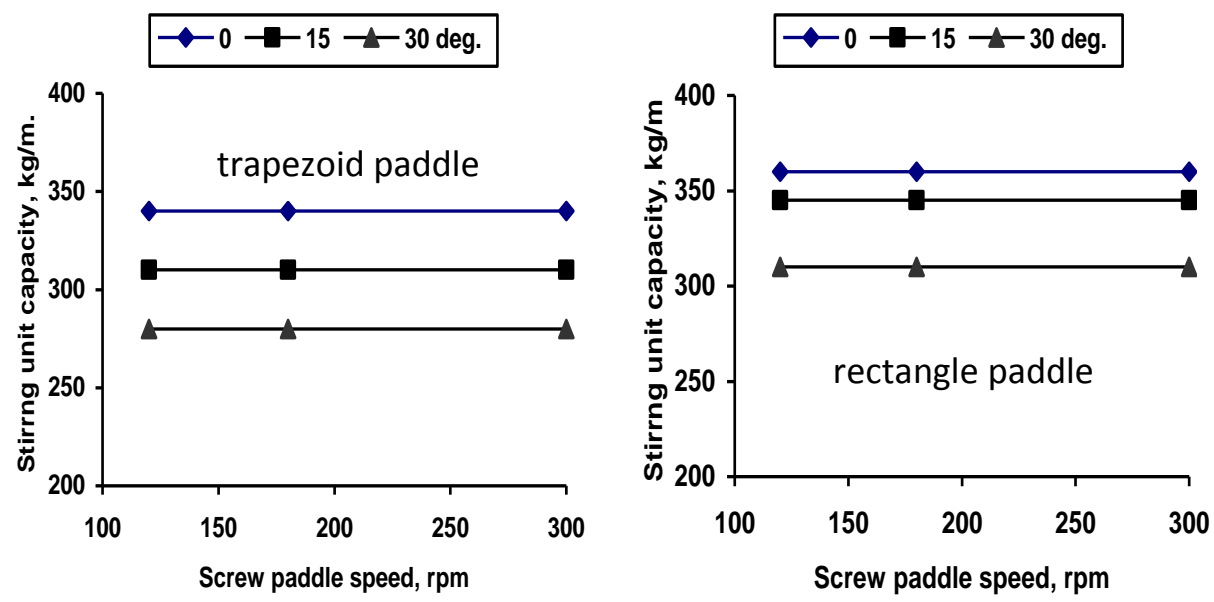

Fig. 10: Effect of screw paddle speed and paddle shape on stirring unit capacity under different inclination angles

Effect of paddle speed and paddle shape on stirring efficiency under different inclination angles

Stirring efficiency is considered the most effective measurement to give a firm decision on screw paddle performance notwithstanding specific power requirements. Fig. 11 referred to the effect of different parameters under study on stirring efficiency. Data conducted that increasing inclination angle from zero to $15^{\circ}$ resulted in increasing stirring efficiency by $4.39 \%$, however increasing the inclination to $30^{\circ}$ resulted in decreasing efficiency by $1.14 \%$ under trapezoid paddle shape. According to decreasing the friction force between paddles and seeds with $30^{\circ}$ the volumetric capacity decreased and consequently decreased stirring efficiency. Using rectangle paddle shape showed similar trend under different parameters. Also, increasing paddle speed resulted in increasing 
stirring efficiency. Increasing paddle speed from $120 \mathrm{rpm}$ to $300 \mathrm{rpm}$ increased stirring efficiency by $10.04 \%$ with inclination angle of $15^{\circ}$. Zero angle or $30^{\circ}$ showed similar trend under all parameters. These results may be attributed to the zero degree caused more friction force of grains with paddle surface. While, under 15 and 30 degree, the inclined position allowed the grains to be stir badly while sliding on paddles which caused less friction force specially with trapezoid paddle shape. Data analyzed showed significant effect of inclination angle and paddle speed on stirring efficiency. $y=0.0294 x+48.886, R^{2}=0.9891$ for zero degree; $\mathrm{y}=0.0355 \mathrm{x}+49.771, \mathrm{R}^{2}=0.9487$ for 15 degree; and $\mathrm{y}=0.0138 \mathrm{x}+$ $49.971, R^{2}=0.9689$ for 30 degree inclination angles.
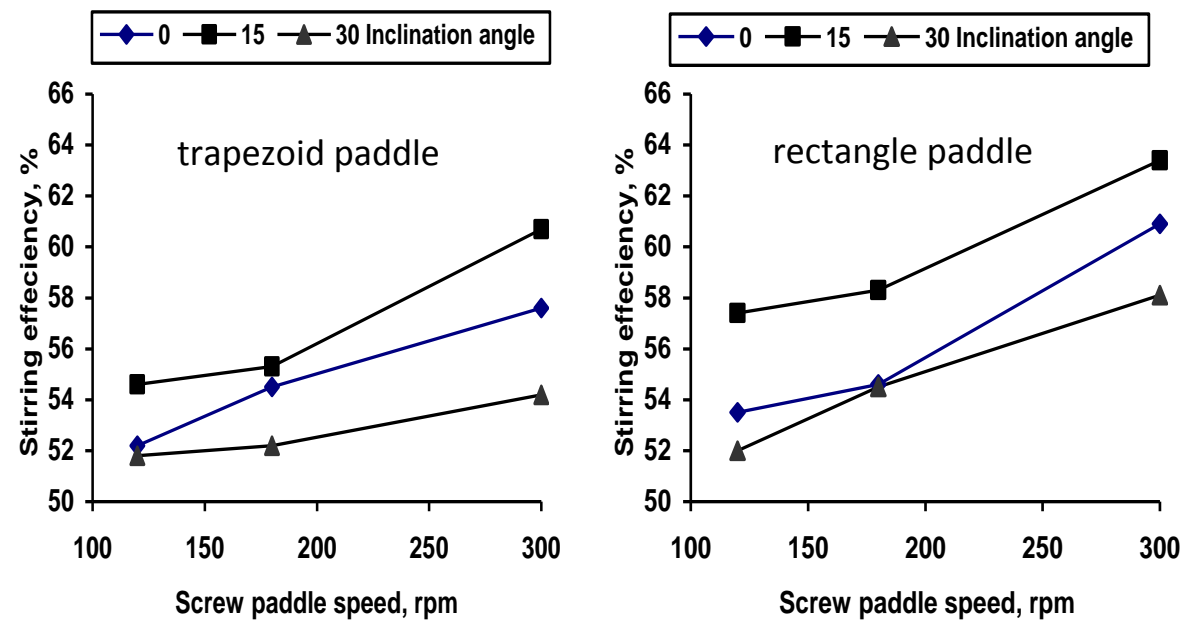

Fig. 11: Effect of screw paddle speed and paddle shape on stirring efficiency under different inclination angles

\section{Total costs:}

The developed stirring unit chassis and other attachments were made of local materials and developed at El-Serw Agricultural Res. Station. According to equation (5), it costs about $650 \mathrm{LE}$ including fabrication, tubeless wheels, lubrication, other attachments and painting depending on the prices of year 2014. One ton of rough rice cost about $24 \mathrm{LE}$ comparing to $49.79 \mathrm{LE}$ by traditional method (by feet) to attain the optimum moisture content for storing. 


\section{CONCOLUSION}

The results could be summarized in the following points:

- Specific power increased by $47.54 \%$ by increasing wheel width from $4 \mathrm{~cm}$ to $10 \mathrm{~cm}$.

- Screw trapezoid paddle shape gave $1.14 \%$ increment for stirring efficiency more than rectangle shape under similar conditions.

- Trapezoid paddle shape showed a value of specific power of $47.54 \%$ comparing with $56.96 \%$ for rectangle shape, capacity increased by $4.42 \%$ and stirring efficiency increased by $4.39 \%$ than triangle paddle shape in all treatments.

- Paddle speed of $300 \mathrm{rpm}$ increased stirring efficiency of $10.04 \%$ than using 120 or $180 \mathrm{rpm}$.

- Inclination angle of $15^{\circ}$ increased stirring efficiency by $4.39 \%$ and $8.8 \%$ for capacity than zero or $30^{0}$ for most treatments.

\section{REFERENCES}

Angledette, A. (1962). Rice Drying Principles and Techniques. Informal Working Bulletin No. 23, FAO, Rome. 73 pp.

Bonazzi, C.; Courteis, F.; Geneste, C.; Lahon, M. C. and Bimbent, J. (1997). Influence of Drying Conditions on the Processing Quality of Rough Rice. Dry. Technol., 15(3, 4): 1141-1157.

Bradburn, N., Blunden, G., Cocker, R.D., Jewers, K. (1993). Aflatoxin contamination of maize. Tropical Science 33 (1), 418-428.

Daniels, M. J., Marks, B. P., Siebenmorgen, T. J., Mc New, R. W., Meullenet, J. F. (1998). Effect of long grain rice storage history on end use quality. Journal of Food Science 63 (1), 832-835.

Dillahunty, A. L., Siebenmorgen, T. J., Buescher, R. W., Smith, D. E., Mauromoustakos, A. (2001). Effect of temperature, exposure duration, and moisture content on color and viscosity of rice. Cereal Chemistry 78 (5), 559-563.

Evanson, R. E., Herdt, R. W., Hossain, M. (Eds.) (1996). Rice Research in Asia: Progress and Priorities. International Research Institute-CAB International, Wallingford, UK, 418p. 
FAO (2013). Agricultural engineering in development - Post-harvest operations http://www.fao.org/documents/en/detail/20980-( 2013)

http://www.ehow.com/how_8665957_sundry-rice.html

Jenkins, B. M. (1989). Field-drying rice using modified swath harvesting. California Agriculture, March-April, 1989: 26-27.

Jeon, Y. W; Halos, S. L. and Elepano, A. R. (1989). Innovations dans les technologies de séchage des grains, In : Céréales en régions chaudes. Conservation \& transformation (pp. 71-83).Agricultural Engineering Department, International Rice Research Institute (IRRI), PO Box 933, Manila, Philippines.

Li, H. and R. V. Morey (1984). Thin-layer drying of yellow dent corn. Transactions of the ASAE: 581-585.

Mendoza. E. E.; Rigor, A. C.; Mordido, C. C. and Marajas, A. A. (1982). Grain Quality Deterioration in On-farm Level of Operations. Proceedings of $5^{\text {th }}$ Annual Grains Postharvest Technology Workshop, Los Baños, 1982. Manila: South East Asia Cooperative Postharvest Research and Development Programme.

Meullenet, J. F., Bradley, C., Griffin, P. M., Daniels, M. J. (1999). Effects of rough rice drying and storage conditions on sensory profiles of cooked rice. Cereal Chemistry 76 (4), 483-486.

Pearce, M.D., Marks, B.P., Meullenet, J. F. (2001). Effects of postharvest parameters on functional changes during rough rice storage. Cereal Chemistry 78 (4), 354-357.

Proctor, D. L. (1994). Grain storage techniques Evolution and trends in developing countries. FAO Agricultural Services Bulletin No. 109

Ranalli, R. P., Howell J. R., T. A., Siebenmorgen, T. J. (2003). Effects of controlled ambient aeration on rice quality during on-farm storage. Cereal Chemistry 80 (1), 9-12.

Soetoyo, R. and Soemardi, R. (1979). The Effect of Thickness of Paddy Sun Drying on Milling Quality. Proceedings of $2^{\text {nd }}$ Annual Grains Post-harvest Workshop, Jakarta, 16-18 January 1979. Manila; South 
East Asia Co-operative Post-harvest Research and Development Programme.

Srivastava, A.C. (1993). Engineering Principals of Agric. Machines ASAE Textbook No. 6 Published the ASAE.

Teter, N. (1987). Paddy Drying Manual. Agricultural Services Bulletin No. 70, FAO, Rome. 123 pp.

Zhou, Z., Robards, K., Helliwell, S., Blanchard, C. (2003). Effect of rice storage on pasting properties of rice flour. Food Research International 36 (1), 625-634.

\section{الملخص العربي \\ تطوير وحدة تقليب آلية لمحصول الأرز بعد الحصاد لتجفيفه \\ مختار قطب أحمد* من من}

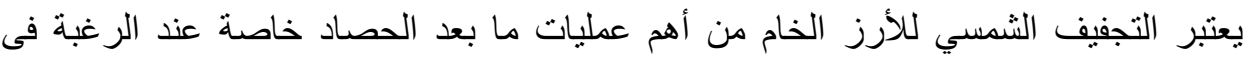

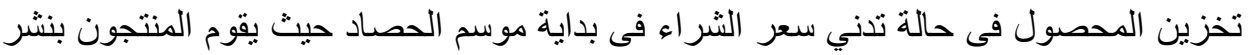

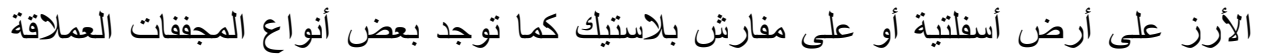

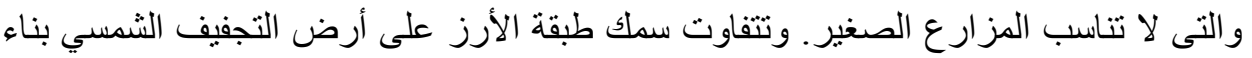

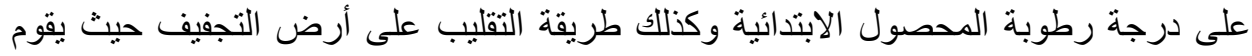

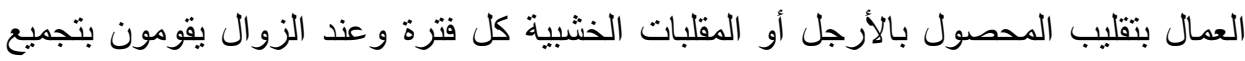

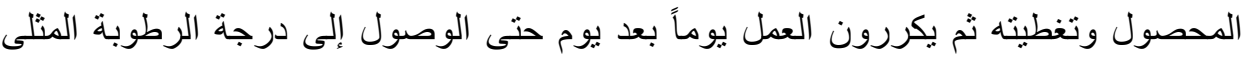

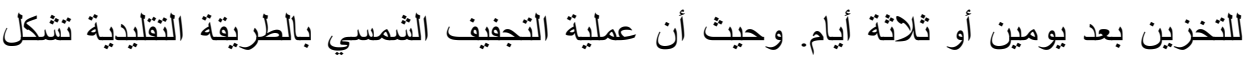

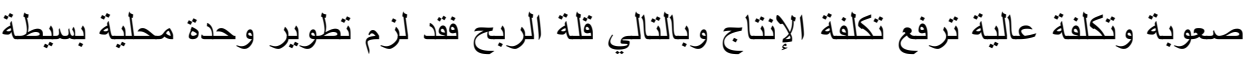

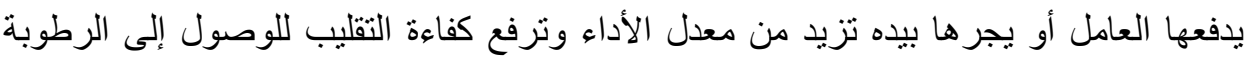
المنلى للتخزين فى أقل زمن مما يقلل تكاليف الإنتاج.

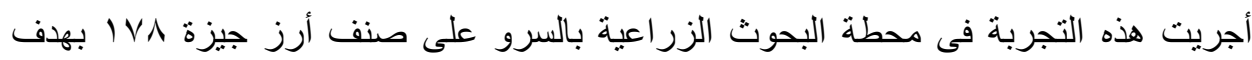
الوصول إلى درجة الرطوبة المطلوبة للأرز قبل التخزين بالية بالستخدام الآلة المطورة ومقارئنة تكاليف التشغيل بالطريقة التقليدية.

فى تجارب مبدئية تم اختبار عرض العجل الكاوتش (ع - • • سم) ونوع المقلب اللازم للتقليب

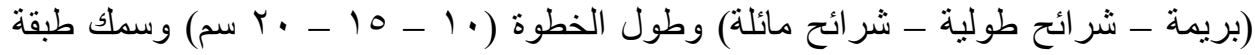

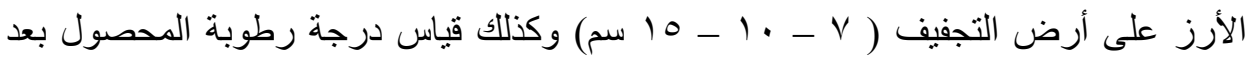

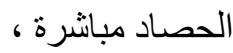

معهد بحوث الهندة الزراعية ـ مركز البحوث الزراعية ـ الدقي - مصر. 


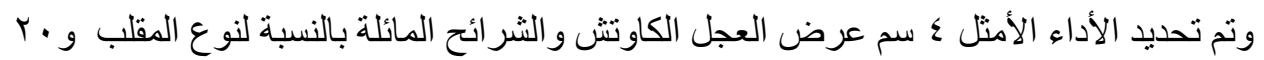
سم طول خطوة المقلب على طبقة أرز سمك 10 سم وتم إجراء باقى التجارب باستخدام هذه المدخلات المدروسة.

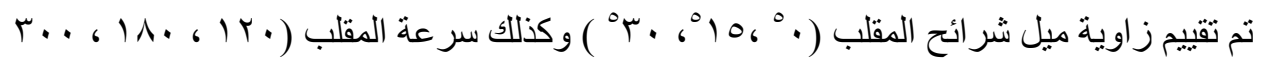
لفة/دقيقة) وكذلك شكل ريش التقليب (شبه منحرف - مستطيل) بقياس القدرة النوعية المطلوبة و السعة الحجمية وكفاءة التقليب بالإضافة إلى التكاليف الكلية ، ويمكن تلخيص النتائج فيما يلي:

أدى استخدام ريش التقليب ذو شكل شبه المنحرف مع زاوية انحراف ريش التقليب

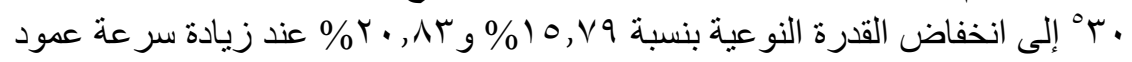

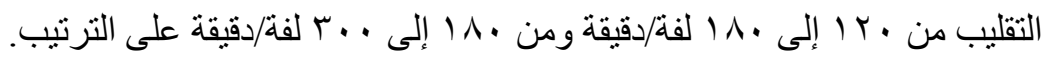

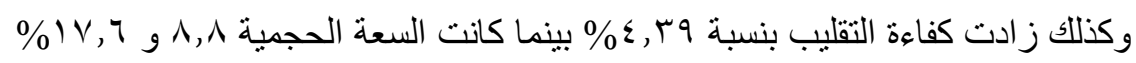

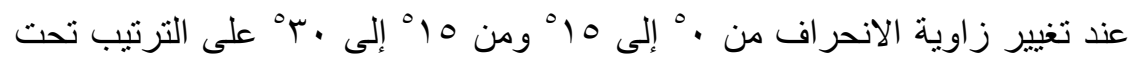
نفس الظروف السابقة.

كان متوسط التكلفة الكلية ؟r جنيه للطن الواحد مقارنة بالطريقة التقليدية حيث يتكلف

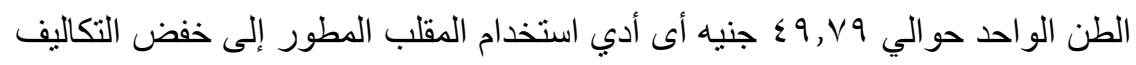

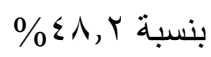

وتوصى الدراسة باستخدام الآلة المطورة فى عملية تقليب الأرز عند سرعة . .. لفة إدقيقة

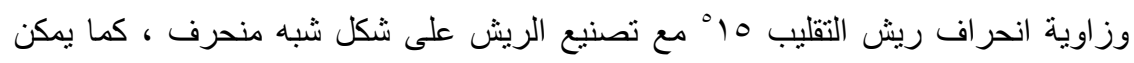

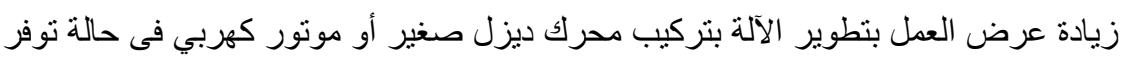
مصدر الطاقة الكهربية. 